\title{
Genomic traits of Klebsiella oxytoca DSM 29614, an uncommon metal-nanoparticle producer strain isolated from acid mine drainages
}

Giuseppe Gallo ${ }^{1 *+}$ (D), Luana Presta ${ }^{2 \dagger}$, Elena Perrin², Michele Gallo ${ }^{3}$, Davide Marchetto ${ }^{3}$, Anna Maria Puglia ${ }^{1}$, Renato Fani ${ }^{2}$ and Franco Baldi ${ }^{3}$

\begin{abstract}
Background: Klebsiella oxytoca DSM 29614 - isolated from acid mine drainages - grows anaerobically using Fe(III)citrate as sole carbon and energy source, unlike other enterobacteria and K. oxytoca clinical isolates. The DSM 29614 strain is multi metal resistant and produces metal nanoparticles that are embedded in its very peculiar capsular exopolysaccharide. These metal nanoparticles were effective as antimicrobial and anticancer compounds, chemical catalysts and nano-fertilizers.

Results: The DSM 29614 strain genome was sequenced and analysed by a combination of in silico procedures. Comparative genomics, performed between 85 K. oxytoca representatives and K. oxytoca DSM 29614, revealed that this bacterial group has an open pangenome, characterized by a very small core genome (1009 genes, about 2\%), a high fraction of unique (43,808 genes, about $87 \%$ ) and accessory genes (5559 genes, about $11 \%)$. Proteins belonging to COG categories "Carbohydrate transport and metabolism" (G), "Amino acid transport and metabolism" (E), "Coenzyme transport and metabolism" (H), "Inorganic ion transport and metabolism" (P), and "membrane biogenesis-related proteins" (M) are particularly abundant in the predicted proteome of DSM 29614 strain. The results of a protein functional enrichment analysis - based on a previous proteomic analysis - revealed metabolic optimization during Fe(III)citrate anaerobic utilization. In this growth condition, the observed high levels of Fe(II) may be due to different flavin metal reductases and siderophores as inferred form genome analysis. The presence of genes responsible for the synthesis of exopolysaccharide and for the tolerance to heavy metals was highlighted too. The inferred genomic insights were confirmed by a set of phenotypic tests showing specific metabolic capability in terms of i) $\mathrm{Fe}^{2+}$ and exopolysaccharide production and ii) phosphatase activity involved in precipitation of metal ion-phosphate salts.

Conclusion: The K. oxytoca DSM 29614 unique capabilities of using Fe(III)-citrate as sole carbon and energy source in anaerobiosis and tolerating diverse metals coincides with the presence at the genomic level of specific genes that can support i) energy metabolism optimization, ii) cell protection by the biosynthesis of a peculiar exopolysaccharide armour entrapping metal ions and iii) general and metal-specific detoxifying activities by different proteins and metabolites.
\end{abstract}

Keywords: Genome, Capsular exopolysaccharide, Ferric-hydroxide gel, Iron, Metal resistance, Metal nanoparticles

\footnotetext{
* Correspondence: giuseppe.gallo@unipa.it

${ }^{\dagger}$ Giuseppe Gallo and Luana Presta contributed equally to this work.

${ }^{1}$ Laboratory of Molecular Microbiology and Biotechnology, Department of

Biological, Chemical and Pharmaceutical Sciences and Technologies, Viale

delle Scienze, ed. 16, 90128 Palermo, Italy

Full list of author information is available at the end of the article
}

(c) The Author(s). 2018 Open Access This article is distributed under the terms of the Creative Commons Attribution 4.0 International License (http://creativecommons.org/licenses/by/4.0/), which permits unrestricted use, distribution, and reproduction in any medium, provided you give appropriate credit to the original author(s) and the source, provide a link to the Creative Commons license, and indicate if changes were made. The Creative Commons Public Domain Dedication waiver (http://creativecommons.org/publicdomain/zero/1.0/) applies to the data made available in this article, unless otherwise stated. 


\section{Background}

The genus Klebsiella embeds different Gram-negative rod shaped bacteria including human pathogens [1], harmless nitrogen-fixing plant endosymbionts [2], and polluted soil inhabitants [3, 4]. Klebsiella oxytoca (formerly known as Klebsiella pneumoniae or Aerobacter aerogenes) is a free-living bacterium isolated from soils [3], plants and animals, including humans. $K$. oxytoca strains can be either pathogenic [5] or beneficial having roles, for instance, as plant growth promoters $[3,6]$ and as valuable biochemical-compound producers [7].

The strain K. oxytoca DSM 29614 (ex BAS-10) was isolated under an iron hydroxides mat from an acid drainage of a pyrite mine at Metalliferous Hills in Southern Tuscany, Italy $[8,9]$. Interestingly, this strain is able to grow using $\mathrm{Fe}(\mathrm{III})$-citrate as sole carbon source under anaerobic condition, producing $\mathrm{Fe}(\mathrm{II})$ from $\mathrm{Fe}(\mathrm{III})$ and a peculiar exopolysaccharide (EPS) containing rhamnose, glucuronic acid and galactose $[10,11]$. The EPS is produced also in the presence of toxic heavy metals, such as $\mathrm{Cd}^{2+}, \mathrm{Pb}^{2+}$ and $\mathrm{Zn}^{2+}$ [12], $\mathrm{As}^{+5}$ and $\mathrm{As}^{+3}$ [13], and $\mathrm{Hg}^{2+}$ [14]. In such conditions, metals often precipitate with EPS in the form of metal nanoparticles embedded in the EPS polymer. This biotechnological peculiarity was used to produce biogenerated "green" metal nanoparticles (NPs) containing: Fe $[15,16], \mathrm{Pd}$, and $\mathrm{Rh}$ that were used for catalytic reactions [17-19]; bimetallic Fe-Pd clusters that were used for hydrodechlorination of chlorobenzene [20] and Aroclor 1260 [21]; Ag that exerts antimicrobial [22, 23] and anticancer [24] activities. Recently, the Fe(III)-EPS was used as a nutraceutical compound in order to improve growth rate of the commercial fungus Tuber borchii by improving $\mathrm{Fe}^{3+}$ uptake [25]. Proteomic analysis performed by 2D-Differential Gel Electrophoresis (2D-DIGE) and mass spectrometry (MS) procedures revealed that protein differential regulation seems to ensure efficient cell growth coupled with EPS production by adapting metabolic and biochemical processes in order to face iron toxicity and to optimize energy production [26]. Altogether, these characteristics prove insights into the remarkable biotechnological usefulness of this bacterium.

Given such an encouraging picture, the aim of this work was to investigate the $K$. oxytoca DSM 29614 genetic features accounting for the synthesis of EPS and heavy metal resistance conferring, thus, the capability of diverse metal nanoparticle (NP) production. To this scope, the $K$. oxytoca DSM 29614 genome was sequenced and analysed by a combination of in silico procedures. Moreover, a set of phenotypic tests was carried out to corroborate the achieved genomic insights.

\section{Methods}

\section{Culture conditions}

Cells of $K$. oxytoca DSM 29614 (ex BAS-10) strain were stored in cryovials at $-80{ }^{\circ} \mathrm{C}$ in $25 \%$ glycerol solution until they were retrieved using Difco Nutrient Broth (BD Bioscience, Italy) growth medium at $30{ }^{\circ} \mathrm{C}$. Aerobic and anaerobic cultivations were performed as described in Buttacavoli et al. (2018) [24].

When the strain was grown in the presence of heavy metals either the $\mathrm{NaC}$ or $\mathrm{FeC}$ media were used. The $\mathrm{NaC}$ medium contains per liter of distilled water: $2.5 \mathrm{~g}$ $\mathrm{NaHCO}_{3}, 1.5$ g N $\mathrm{NH}_{4} \mathrm{Cl}, 1.5 \mathrm{~g} \quad \mathrm{MgSO}_{4} .7 \mathrm{H}_{2} \mathrm{O}, 0.6 \mathrm{~g}$ $\mathrm{NaH}_{2} \mathrm{PO}_{4}, 0.1 \mathrm{~g} \mathrm{KCl}$, and $14.7 \mathrm{~g} \mathrm{Na}(\mathrm{I})$-citrate (Carlo Erba, Italy). The $\mathrm{NaC}$ medium was buffered at $\mathrm{pH} 7.8$ with a solution of $\mathrm{NaOH}$. In the $\mathrm{FeC}$ medium $50 \mathrm{mM} \mathrm{Fe}$ (III)-citrate replaces $50 \mathrm{mM} \mathrm{Na-citrate} \mathrm{[27].} \mathrm{The} \mathrm{growth} \mathrm{of} \mathrm{the} \mathrm{strain}$ was monitored determining total protein content by using Protein Assay kit (Bio-Rad, Italy), based on Bradford dye-binding method (1976) [28], according to manufacturing instruction for micro-assay.

\section{DNA isolation and whole genome sequencing}

K. oxytoca DSM 29614 strain was grown at $30{ }^{\circ} \mathrm{C}$ using Difco Nutrient Broth (BD Bioscience, Italy) growth medium. The genomic DNA was extracted using the CTAB method [29] and the authenticity of the genomic DNA was confirmed by $16 \mathrm{~S}$ rRNA gene sequencing (Ylichron Srl, Italy). Whole genome shot-gun sequencing was performed by using the Illumina HiSeq system (Illumina Inc., San Diego, CA) with a paired-end approach loading genomic DNA onto one single flowcell (BGI-HongKong Co. limited, Hong Kong).

\section{Phylogenetic analysis}

16S rRNA gene sequences from strains belonging to $K$. oxytoca were selected from NCBI ftp site to run a phylogenetic analysis. Sequence alignment and phylogenetic tree were obtained as previously described in Presta et al. (2017) [30].

\section{Genome assembly and annotation}

Poor quality bases were removed using the dynamic trimming algorithm embedded in the SolexaQA suite [31] selecting a Phred score threshold value of 13 . Assembly was performed by using ABySS 1.3.7 software [32]. The resulting contigs were launched in a multidraft-based scaffolder MeDuSa [33] which starting from 307 initial contigs generated 62 scaffolds. The last ones were then annotated by using NCBI Automated Genome Annotation Pipeline.

\section{Comparative genomics}

All the $85 K$. oxytoca representative (Additional file 1 : Table S1) genomes sequenced up to date (i.e. September 2016) were collected from the NCBI ftp site (ftp:// 
ftp.ncbi.nlm.nih.gov/genomes/refseq/bacteria/Klebsiella_oxytoca/all_assembly_versions/) and, alongside $K$. oxytoca DSM 29614 genome, they were analyzed using Roary software [34] to identify shared orthologous and strain-specific genes.

\section{Identification of genes putatively involved in metal tolerance, secondary metabolite biosynthesis and antibiotic resistance}

AntiSMASH software [35] for genome-wide identification, annotation and analysis of secondary metabolite biosynthetic gene clusters was used to scan the genome sequence of $K$. oxytoca DSM 29614 in order to identify gene clusters involved in secondary metabolite production.

BacMet database [36] was used to identify the genetic elements responsible for heavy metal resistance, by using BLASTp algorithm with a threshold e-value $\leq 0.0001$ and percentage identity $\geq 30$.

\section{Protein functional enrichment analysis}

Protein functional enrichment analysis was performed using the SmartTables tool at BioCyc database collection [37] with the option "Fisher Exact Parent-Child Union" (FEPCU) on. Two analyses were performed on the sets of differentially abundant proteins (Additional file 2: Table S2) obtained from the proteomic analyses described in Gallo et al. (2012) [26]. In particular, up-regulated proteins i) in $\mathrm{FeC}$ versus $\mathrm{NaC}$ in anaerobic condition and ii) in anaerobic versus aerobic $\mathrm{FeC}$ cultivations were used. For these analyses, the $K$. oxytoca $10-$ 5243 (NCBI accession JH603143.1) was chosen as reference strain since it was the most related strain among the selectable ones at BioCyc database collection according to the phylogenetic tree based on $K$. oxytoca $16 \mathrm{~S}$ rRNA gene sequences (Fig. 1).

\section{EPS extraction and determination}

Aliquots of $10 \mathrm{ml}$ of of DSM 29614 anaerobic culture in FeC medium were sampled at different times. The samples were firstly centrifuged to eliminate bacterial cells, then precipitation of polysaccharides was induced by treating the supernatant with $8 \mathrm{ml}$ of cooled ethyl alcohol (95\%). The purification phase was repeated twice. The concentration of total carbohydrate in EPS was quantified spectrophotometrically $(485 \mathrm{~nm})$ as glucose (Fluka, Germany) equivalents after reaction with $96 \%$ sulfuric acid (Fluka, Germany) and 5\% phenol (Fluka, Germany) [38]. Iron removal from polysaccharide was performed by treat-

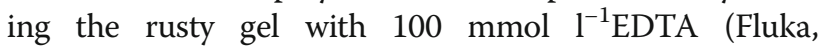
Germany) until it was colorless [10].

\section{Determination of total iron and $\mathrm{Fe}(\mathrm{II})$}

In order to quantify iron species in K. oxytoca DSM 29614 cultivations, 3-ml aliquots were collected at different times

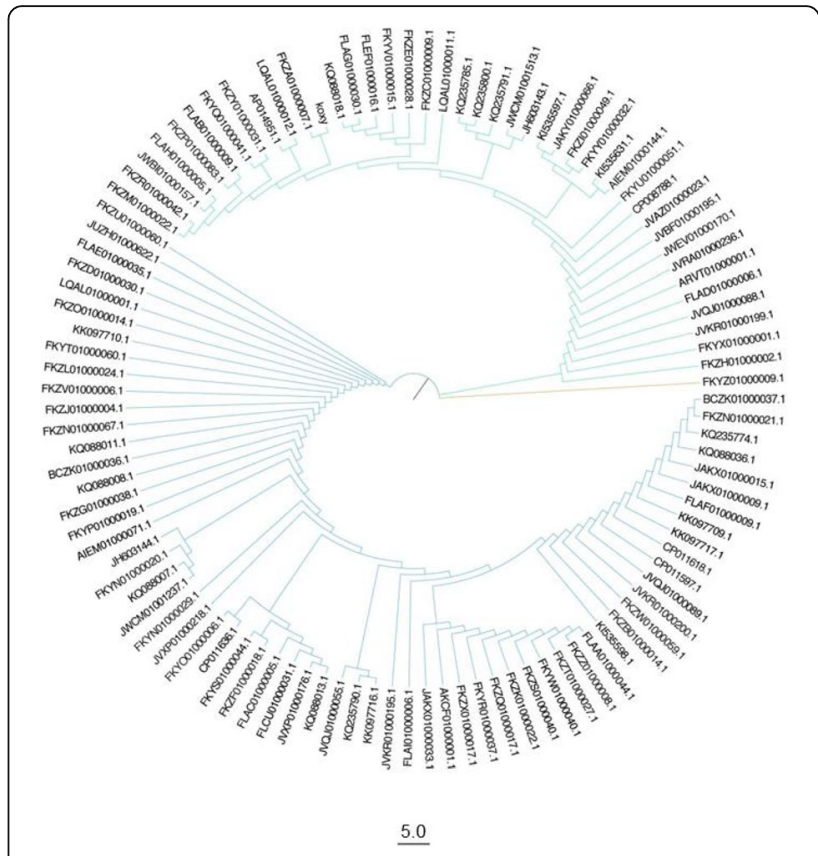

Fig. 1 Phylogenetic tree based on 16S rRNA gene sequences of $K$. oxytoca representatives. K. oxytoca DSM 29614 is reported as koxy

and processed for colorimetric assay as previously described in Baldi et al. (2009) [10].

\section{Struvite formation and determination}

A $100 \mathrm{ml}$ of $\mathrm{NaC}$ medium was inoculated with $1 \mathrm{ml}$ of K. oxytoca DSM 29614 $\left(\mathrm{OD}_{600 \mathrm{~nm}}=01 \mathrm{ABS}\right)$ and after $3 \mathrm{~h}$ of incubation at $30{ }^{\circ} \mathrm{C}$, each culture was amended with $5 \mathrm{mg}$ of $\mathrm{Ag}\left(\mathrm{NO}_{3}\right), \mathrm{Hg}\left(\mathrm{NO}_{3}\right)_{2}$ or $\mathrm{Pd}\left(\mathrm{NO}_{3}\right)_{2}$ (Sigma-aldrich, Germany). The cultures were incubated at $30{ }^{\circ} \mathrm{C}$ in static mode until colloidal material and the crystals precipitated. Crystals were easily separated by filtration from colloidal fraction and the determination of crystal was performed with X-ray-Diffractometry (Bruker D8, Italy) with $40 \mathrm{kV}$ and $40 \mathrm{~mA}$ geometry with $\mathrm{Cu} \mathrm{K \alpha}(\lambda=0.154 \mathrm{~nm})$ radiation. The micro-crystals formed in the cultures added with $\mathrm{Pd}^{2+}$ were observed by optical microscopy (Axio-Imager Z1stand, Zeiss, Italy) equipped with Axiocam MRm 2.8 in transmission and in fluorescence modes. The specimens were stained with DAPI (Fluka, Germany) to observe cells involved in crystal precipitation.

\section{TEM observation of struvite}

A Pd-EPS aliquot of $1 \mathrm{mg}$ was suspended in $1 \mathrm{ml}$ of milli-Q water and sonicated for $10 \mathrm{~min}$. Then, in order to obtain TEM images a $5 \mu \mathrm{l}$ aliquot of each suspension was processed as previously described in Battistel et al. (2015) [23]. 
Determination of metals in struvite

Total metals in $10 \mathrm{mg}$ of crystals from K.oxytoca DSM 29614 culture was determined in triplicates. The sample was mineralized with aqua-regia for $4 \mathrm{~h}$ at $70{ }^{\circ} \mathrm{C}$. The total metals were determined by flameless Atomic Absorption Spectroscopy (Varian SpectrAA 250 Plus, Italy).

\section{Determination of alkaline phosphatase activity}

The K. oxytoca DSM 29614 cells were harvested from aerobic and anaerobic $\mathrm{NaC}$ and $\mathrm{FeC}$ media without metal additions and with additions of $\mathrm{AgNO}_{3}, \mathrm{Hg}\left(\mathrm{NO}_{3}\right)_{2}$ or $\mathrm{Pd}\left(\mathrm{NO}_{3}\right)_{2}$ (Sigma-aldrich, Germany). The cells were harvested by centrifuging, washed and then recovered in $5 \mathrm{ml}$ of carbonate buffer constituted by $0.095 \mathrm{M} \mathrm{NaHCO}_{3}$, $0.005 \mathrm{M} \mathrm{Na}_{2} \mathrm{CO}_{3}, 0.1 \mathrm{M} \mathrm{NaCl}, 0.05 \mathrm{M} \mathrm{MgCl}_{2}$, at pH 8.5.

Aliquots of $3 \mathrm{ml}$ of cell suspension were lysed on ice bath by a Vibra-Cell VC50 sonicator (Sonics \& Materials, Newtown, USA), equipped with a 3-mm microtip. Two cycles of $45 \mathrm{~s}$ of pulsed sonication (30 s of pulse and $15 \mathrm{~s}$ of pause) were performed for each sample. The sonicator was set to $20 \mathrm{kHz}$, with a power output of $50 \mathrm{~W}$. Cytosol with phosphatase activity was collected after centrifugation (20 min. at 14,100 g). The supernatant was recovered, filtered $(0.02 \mathrm{~mm}$ pore size $)$ and stored at $-20{ }^{\circ} \mathrm{C}$ until phosphatase assay was performed [39]. The supernatant (cytosol) and the pellet (cell membranes) were characterized for total protein concentration by Coomassie Blue dye (Biorad, Italy) assay protocol [28].

The enzymatic activity was determined in the presence of different concentrations of the fluorescence substrate MUF- $\mathrm{PO}_{4}$ (Sigma-Aldrich, Germany) [40] in order to determine $\mathrm{V}_{\max }$ and $\mathrm{K}_{\mathrm{m}}$. The florescence intensity was measured by using a spectrofluorometer (Victor mod. $\mathrm{X} 2$, Perkin-Elmer). The fluorescence excitation $\left(\mathrm{E}_{\mathrm{ex}}\right)$ and emission $\left(E_{e m}\right)$ wavelengths were set up at 380 and $480 \mathrm{~nm}$, respectively. The calculation of phosphatase activity (PA) was performed within a range of $\mathrm{MUF}-\mathrm{PO}_{4}$ between 10 to $1000 \mu \mathrm{M}$. The PA activity is expressed as "IU", namely the enzyme activity unit, which transforms $1 \mu \mathrm{M}$ per minute of substrate. Than the PA, reported as international unit (IU), is normalized to the cell biomass calculated as grams of proteins ( $\left.\mathrm{gRRT}_{\mathrm{PR}}\right)$.

\section{Results}

\section{K. oxytoca DSM 29614 genome}

The whole-genome shotgun project has been deposited at NCBI WGS database under the accession number MKCU00000000 and the version reported in this work was named MKCU01000000. The genome is 6,257,287 bp long with a GC content of $51.85 \%$, similarly to other members of the same species. Other main features of the genome are reported in Table 1.

Comparative genomics analyses were performed between all the 85 previously named $K$. oxytoca representatives
Table 1 Main features of Klebsiella oxytoca DSM 29614 genome

\begin{tabular}{lll}
\hline Features & & $\mathrm{n}^{\circ}$ \\
\hline Genes & Total & 5968 \\
& Coding & 5739 \\
CDS & Total & 5924 \\
& Coding & 5739 \\
CRISPR Arrays & & 1 \\
ncRNAs & & 7 \\
tRNAs & & 34 \\
rRNAs & Total & $1(5 S) ; 2(16 S)$ \\
& Complete & $1(5 S) ; 1$ (16S) \\
& Partial & $1(16 S)$ \\
Pseudo Genes & Total & 185 \\
& Ambigous residues & 1 \\
& Frameshifted & 40 \\
& Incomplete & 143 \\
& Internal stop & 16 \\
& Multiple problems & 14 \\
\hline
\end{tabular}

(Additional file 1: Table S1) and K. oxytoca DSM 29614; the phylogeny of the genus has been also investigated and the diversity and composition of the global gene repertoire has been studied through the pangenome approach analysis, as described in Materials and Methods.

Despite the phylogenetic analysis revealed that the $16 \mathrm{~S}$ rRNA coding sequences can be included into three main clusters (Fig 1), the phylogenetic history of these organisms appears to be very complex. In this regard, the data obtained by evaluating the number of conserved genes

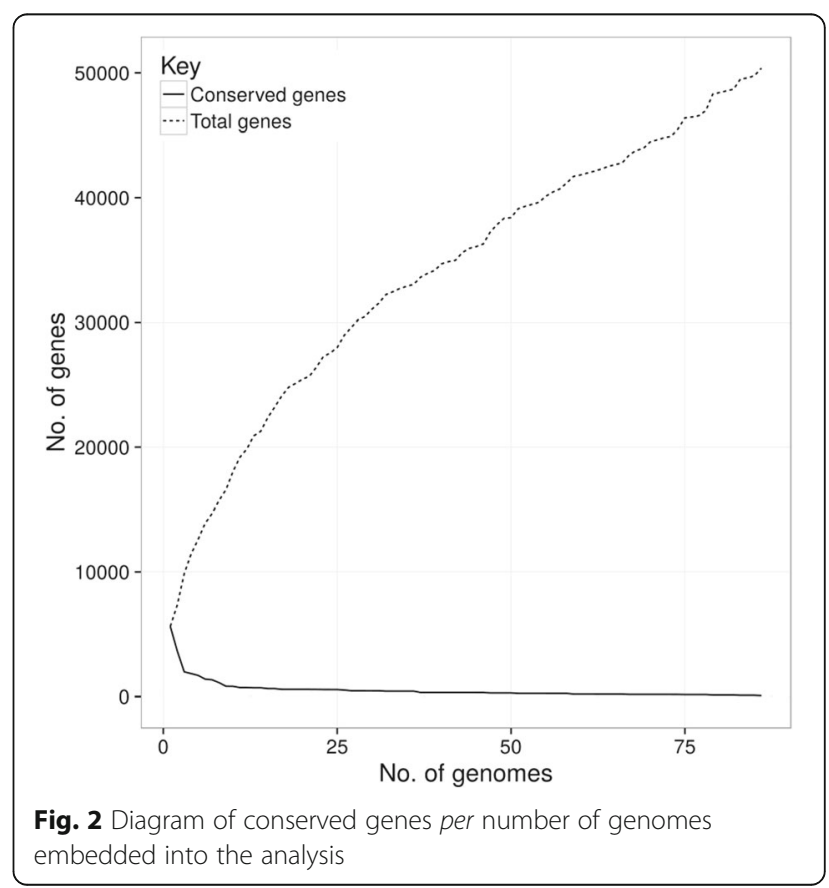


vs. the number of total genes (plotted in Fig. 2) revealed that this group of microorganisms has an open pangenome - i.e. the number of unique and accessory genes increases with the number of genomes embedded into the analysis. Moreover, Fig. 3 shows the size of unique, accessory and core genomes. The core genome, here presented as soft-core and proper core, consists of 1009 genes (about $2 \%$ of the total), whereas there is a high fraction of unique $(43,808$ genes, about $87 \%)$ and accessory genes (5559 genes, about $11 \%$ ).

A deeper functional characterization of $K$. oxytoca DSM 29614 genome has been obtained by mapping its open-reading frames (ORFs) to the COG database [41]. Data obtained are shown in Fig. 4 reporting the abundance of genes assigned to each category. Such analysis revealed that proteins belonging to COG categories "Carbohydrate transport and metabolism" (G), "Amino acid transport and metabolism" (E), "Coenzyme transport and metabolism" $(\mathrm{H})$, "Inorganic ion transport and metabolism" $(\mathrm{P})$, and "membrane biogenesis-related proteins" (M) are particularly abundant in the predicted proteome.

\section{Insights from genomics for Fe(III)-citrate fermentation capability}

According to previous data [12], medium acidification occurs when DSM 29614 strain is incubated in presence of citrate under anaerobic conditions while medium $\mathrm{pH}$ is stable when the strain is incubated aerobically in presence of citrate (Fig. 5a). Indeed, the DSM 29614 strain genome contains the genes encoding citrate lyase (CitEF), $\mathrm{Na}^{+}$-dependent membrane oxaloacetate decarboxylase (OadA), pyruvate formate lyase (PFL), phosphotransacetylase (PTA) and acetate kinase (ACK), that are the enzymes required for anaerobic citrate utilization [42]. Interestingly, the differential representation of these enzymes was already described in two differentially abundant protein sets in Gallo et al. (2012) [26]. In the present work, these two protein sets (Additional file 2:

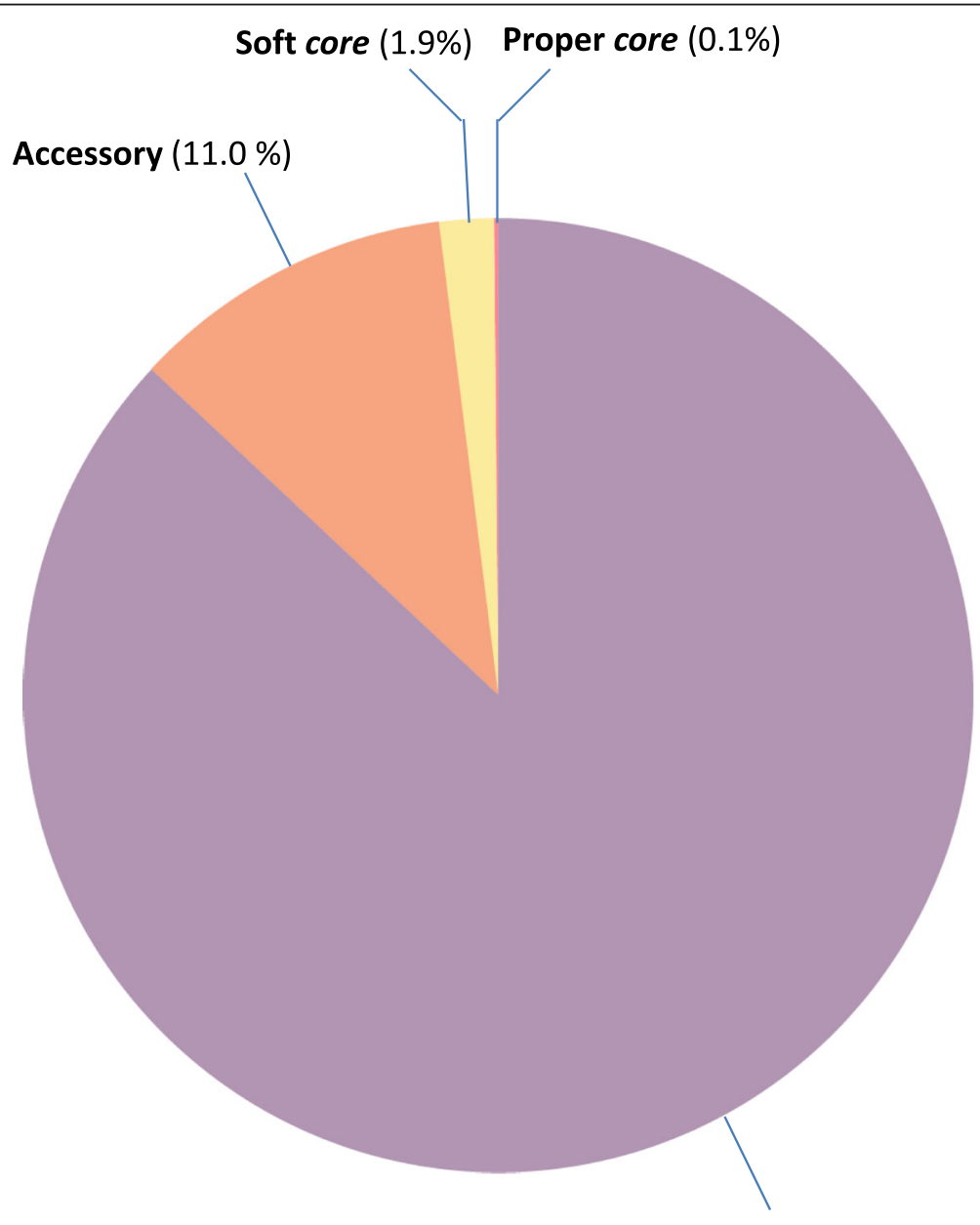

Unique $(87.0 \%)$

Fig. 3 Diagram showing the percentage of core, soft-core, accessory, and unique genes of the K. oxytoca DSM 29164 genome 
12

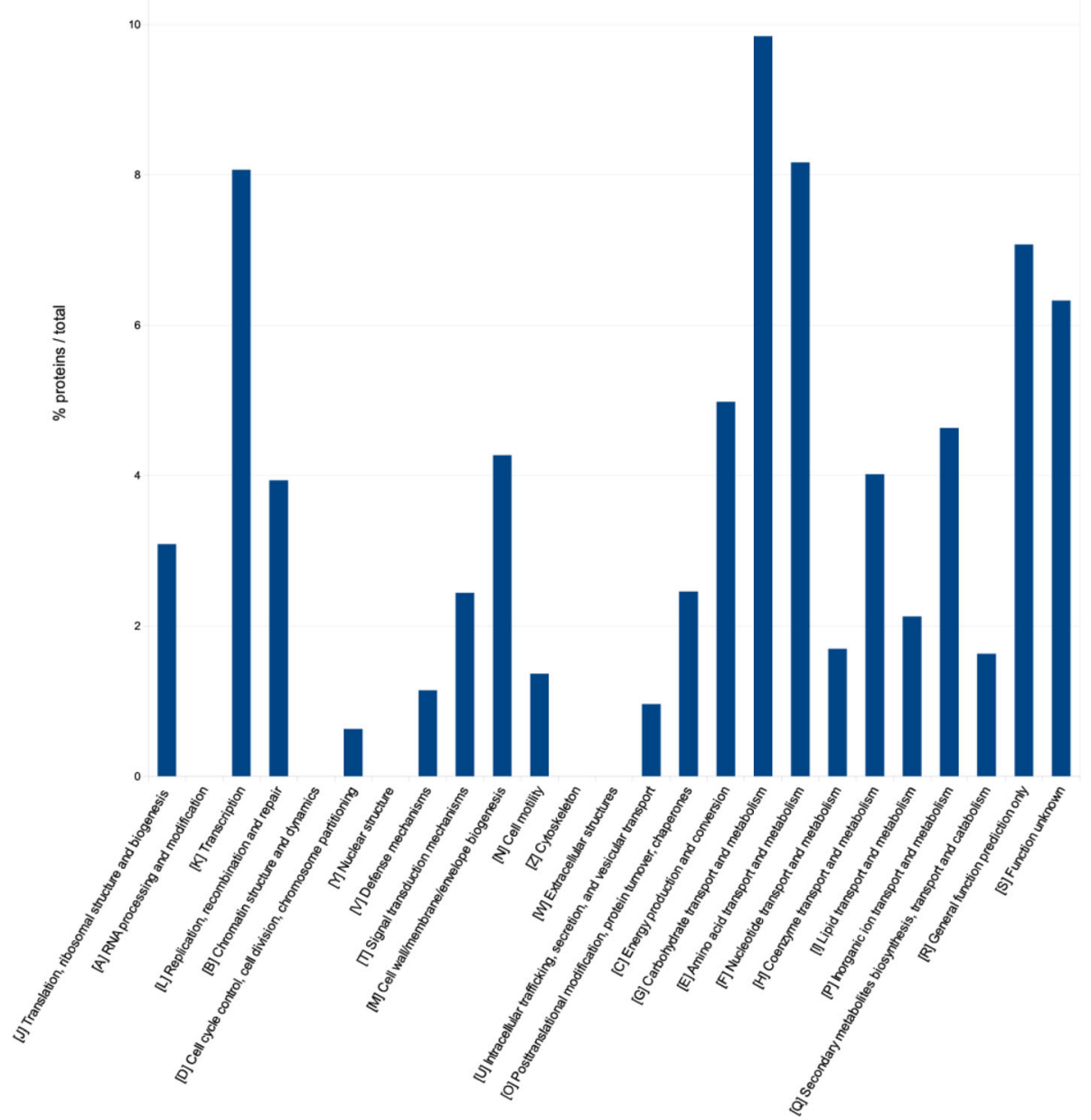

Fig. 4 Proteins abundance per COG functional categories of K. oxytoca DSM 29614 genome

Table S2) were used for a BioCyc-based functional enrichment analysis whose results are available at the internet address https://biocyc.org/smarttables as BioCyc Public Smart Tables "Enriched with FEPCU from anaerobic Vs aerobic growth on $\mathrm{FeC}$ up-regulated proteins" and "Enriched with FEPCU from $\mathrm{FeC}$ Vs $\mathrm{NaC}$ during anaerobic growth up-regulated proteins". In particular, these results revealed an up-regulation of enzymes belonging to i) a super pathway including glycolysis, pyruvate dehydrogenase, TCA and glyoxylate bypass, ii) fermentation pathways including the one forming acetate, and iii) anaerobic respiration during anaerobic utilization of $\mathrm{Fe}(\mathrm{III})$-citrate as carbon and energy source. Thus, this result further supports the capability of the DSM 29614 strain to optimize energy production.

Another intriguing aspect of DSM 29614 strain is the massive reduction of $50 \mathrm{mM}$ of $\mathrm{Fe}^{3+}$ to $22 \mathrm{mM} \mathrm{Fe}$ during anaerobic growth on $\mathrm{FeC}$ medium (Fig. 5b). A BLAST interrogation revealed that the genome of DSM 29614 strain does not contain genes homologous to those found in Shewanella - like cymA, mtrABC operon, $m t r F$ and omcA - or in Geobacter - such as omcS, omcT, $d h c 2$ and $p c c F$ - involved in dissimilatory $\mathrm{Fe}(\mathrm{III})$ reduction [43-46]. However, the DSM 29614 strain possesses genes that can have a role in iron transport and reduction. Among them there are: fecABCDE operon (BI322_RS14055- BI322_RS14075) that is devoted to Fe(III)-citrate uptake in bacterial cells [47]; genes encoding flavin metal reductases, like the flavodoxin FldA (BI322_RS16850), the NADPH-dependent ferric siderophore reductase (BI322_RS21400), the succinate dehydrogenase flavoprotein subunit (BI322_RS16715), and the flavocytochrome C (BI322_RS10335); genes encoding ion efflux pumps, such as the cation transporter FieF 


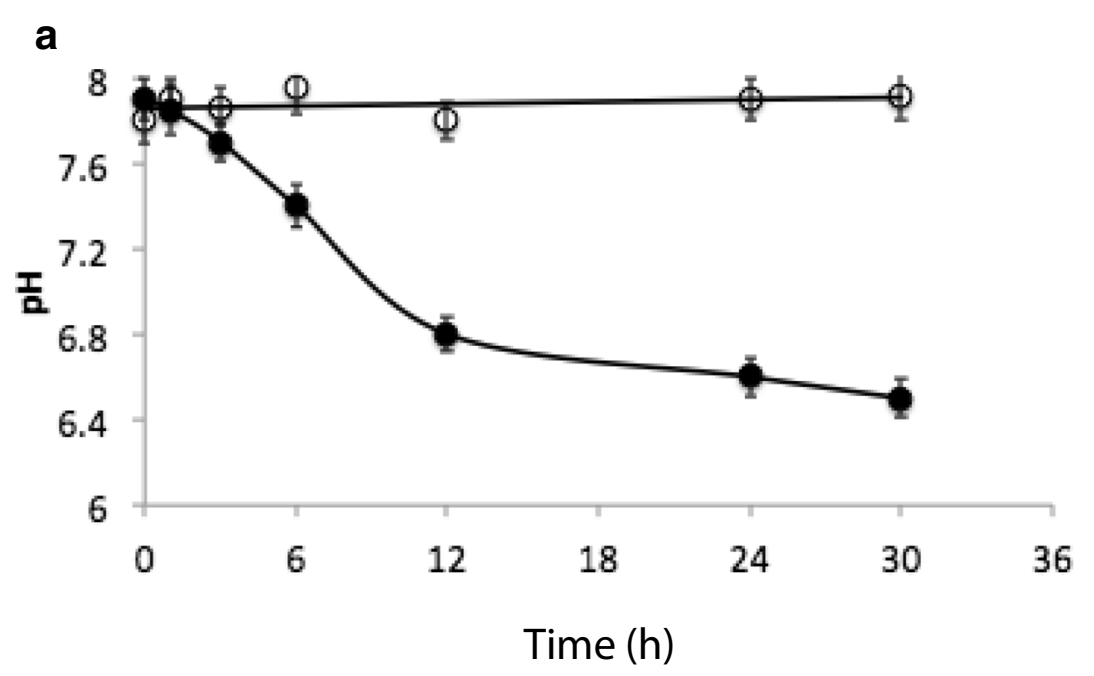

b

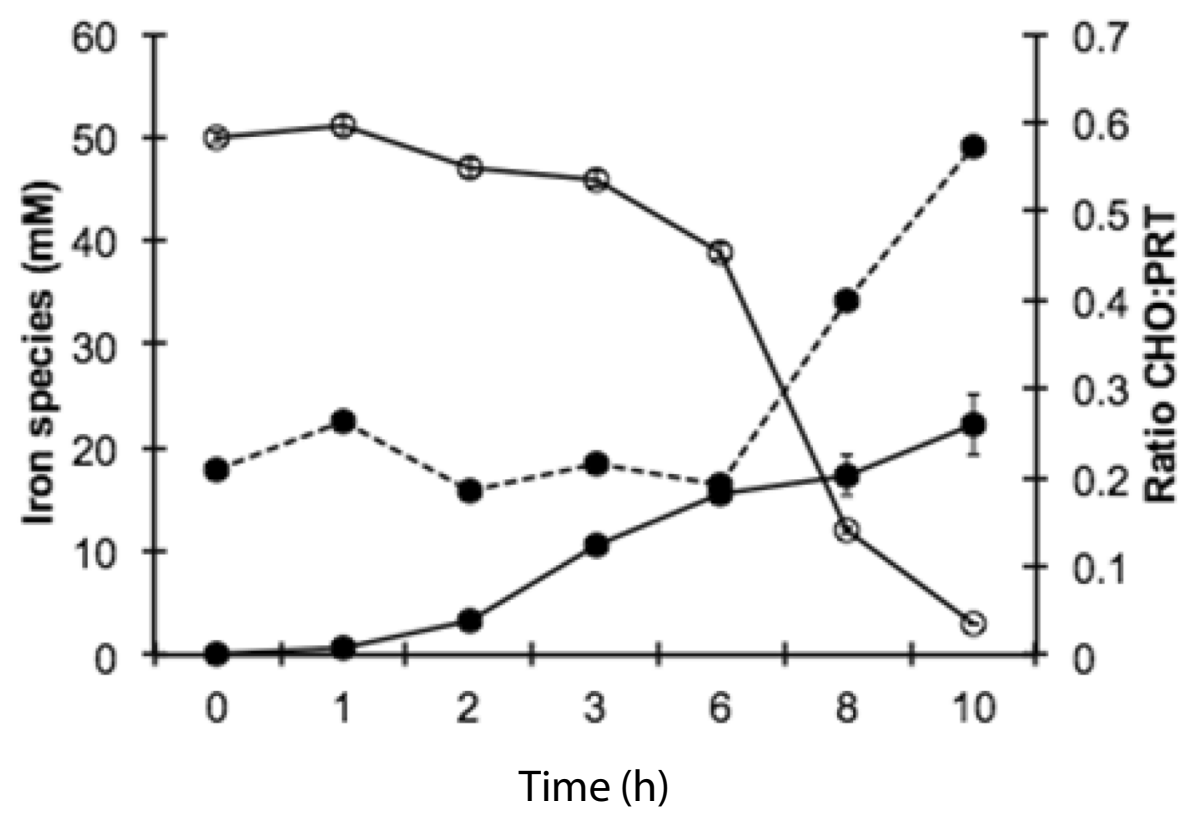

Fig. 5 a Medium pH in K. oxytoca DSM 29614 cultures performed in FeC (empty circles) and in NaC (solid circles) medium under aerobic and anaerobc condition, respectively. $\mathbf{b}$ Determination of total Fe (empty circled), $\mathrm{Fe}^{2+}$ (solid circles) and ratio between polysaccharide (CHO) and proteins (PRT) of harvested DSM 29614 cells during anaerobic growth in FeC medium. Standard deviation values are reported as vertical bars

(BI322_RS11975) [45, 48]. In particular, the NADPHdependent ferric siderophore reductase is one of the 33 gene products involved in iron tolerance predicted in DSM 29614 strain genome (Fig. 6; Additional file 3: Table S3), and both the succinate dehydrogenase flavoprotein subunit and the flavocytochrome $\mathrm{C}$ are predicted to play a role in the anaerobic respiration of fumarate according to KEGG database. Indeed, the succinate dehydrogenase flavoprotein subunit was upregulated in anaerobic $\mathrm{FeC}$ cultivation in the respect of both aerobic
FeC cultivation and anaerobic $\mathrm{NaC}$ cultivation as previously revealed by differential proteomics [26].

In addition, the ability to produce bioactive compounds capable of acquiring Fe(III) was revealed by antiSMASH analysis showing the presence of a turnerbactin biosynthetic gene cluster (from BI322_RS17265 to BI322_ RS17505). Indeed, turnerbactin is a triscatecholate siderophore synthetized through a Non Ribosomal Peptide Synthetase, which was firstly isolated from the shipworm endosymbiont Teredinibacter turnerae T7901 [49]. 


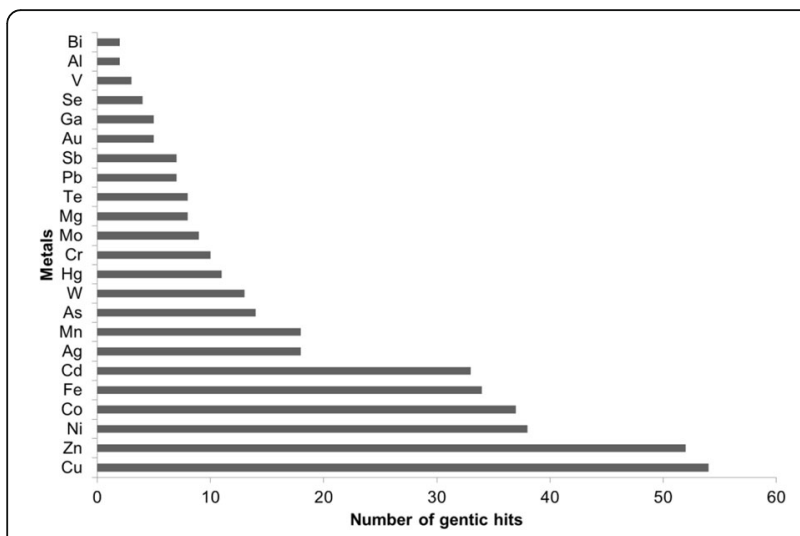

Fig. 6 Number of genes, having homologues in K. oxytoca DSM 29614, putatively associated with tolerance to different metals according to BacMet database [36]

\section{Correlation between metal tolerance and genomic traits}

A crucial contribution to tolerance to high levels of iron can be ascribed to the peculiar EPS produced by DSM 29614 strain which promotes metal ion entrapment and reduction. In fact, when the strain grows anaerobically in the presence of $\mathrm{FeC}$, in concomitance to the $\mathrm{Fe}^{3+}$ reduction to $\mathrm{Fe}^{2+}$, iron also precipitates in the bacterial EPS (Fig. 5b; Additional file 4: Figure S1) [22]. In these growth conditions the $\mathrm{pH}$ is low and the citrate is consumed, but the increased ratio between polysaccharides $(\mathrm{CHO})$ and cell proteins (PRT) in harvested cells at stationary phase demonstrated an overproduction of EPS (Fig. 5b).

Two cps gene clusters, namely cps 1 and cps 2 (Tables 2 and 3 , respectively) were identified in the genome supporting the capability of $K$. oxytoca DSM 29614 cells to synthesize the EPS. Indeed, some features of cps 1 and cps2, including their corresponding flanking regions in the genome, highlight peculiar characteristics of $K$. oxytoca DSM 29614 as described in (Additional file 5: Supporting Information).

In addition to tolerance to high levels of iron, the DSM 29614 strain possesses a high level of tolerance to diverse metals such as $\mathrm{Pd}, \mathrm{Rh}, \mathrm{Cd}, \mathrm{Pb}, \mathrm{Zn}, \mathrm{As}, \mathrm{Hg}$ and $\mathrm{Ag}$ as already mentioned. Therefore, in order to detect genetic elements putatively responsible for this capability, BacMet database [36] was used to scan the DSM 29614 strain genome. This investigation allowed to detect 149 genes putatively responsible for specific resistance to a total of 23 different kinds of metals (Fig. 6; Additional file 3: Table S3 and Additional file 5: Supporting Information).

\section{Phosphatase activity and metal cation precipitation} K. oxytoca DSM 29614 genome contains typical pho regulon genes [50] - like phoA, phoR, phoB, phoE and pstSABC - and acid phosphatases - including a phosphatase PAP2 family protein which is part of cps1 gene cluster. The overall phosphatase activity (oPA) of DSM 29614 strain was investigated using samples collected from four different experimental sets: cultivations using $\mathrm{FeC}$ or in $\mathrm{NaC}$ media under anaerobic or aerobic conditions (Fig. 7). The highest oPA was observed in the $\mathrm{NaC}$ medium under anaerobic condition while the lowest oPA was revealed in $\mathrm{FeC}$ medium under aerobic condition. The $\mathrm{V}_{\text {max }}$ and $\mathrm{K}_{\mathrm{m}}$ of oPA in cells cultivated under anaerobic conditions in $\mathrm{NaC}$ medium are by far the highest in respect to the other growing conditions (Table 4). The addition of increasing amounts of inorganic phosphate to $\mathrm{NaC}$ medium causes a modest but appreciable oPA decrement only in anaerobic condition, with a maximum reduction of approximately $22 \%$ comparing 25 and $500 \mu \mathrm{M}$ (Fig. 8a). On the contrary, the addition of heavy metals to $\mathrm{NaC}$ growth medium strongly stimulates oPA in aerobiosis only (Fig. 8b). Indeed, the formation of struvite $\left(\mathrm{MgNH}_{4} \mathrm{PO}_{4} \cdot 6 \mathrm{H}_{2} \mathrm{O}\right)$ was revealed in $K$. oxytoca DSM 29614 cultivations performed using $\mathrm{NaC}$ growth medium under aerobic conditions with the addition of different heavy metals. In particular, the addition of $50 \mathrm{mg} \cdot \mathrm{l}^{-1} \mathrm{Hg}^{2+}$ or $\mathrm{Ag}^{+}$induced the formation of millimetric struvite crystals (Additional file 4: Figure S2 A and B) as well as the addition of $\mathrm{Pd}^{2+}$ induced the formation micrometric struvite crystals (Additional file 4: Figure S2 C and D). The presence of $\mathrm{Ag}^{+}$on struvite crystal surface, inferred from crystal face darkening, was confirmed by the spectrophotometric analysis revealing a content of $0.03 \pm$ $0.01 \%(w / \mathrm{w})$.

\section{Discussion}

The $K$. oxytoca DSM 29614 genome has peculiar characteristics which reveal a complex phylogenetic history of this microorganism. The results of the comparative genomic analysis performed using $85 \mathrm{~K}$. oxytoca strains are in agreement with the comparative analysis of $K$. pneumoniae strain genomes [51] highlighting the enormous capacity of the strains belonging to Klebsiella genus to acquire (and use) exogenous DNA. Indeed, such genetic variability is typical of those groups of microorganisms that usually inhabit different niches and/or living in large (and complex) communities. Accordingly, members of Klebsiella genus are able to colonize diverse environments and to adapt to a range of lifestyle [52, 53]. In particular, the relative abundancies of COG categories inferred from K. oxytoca DSM 29614 genome could be ascribed to the necessity to survive in hazardous and metabolically demanding environments, like that in which the strain has been isolated. Accordingly, the DSM 29614 strain possesses the unique capability among the $K$. oxytoca members of growing using $\mathrm{Fe}(\mathrm{III})$-citrate as the sole carbon 
Table 2 The cps 1 gene cluster of K. oxytoca DSM 29614

\begin{tabular}{|c|c|c|c|c|c|}
\hline \multirow{2}{*}{$\begin{array}{l}\text { Gene (Locus } \\
\text { tag) }\end{array}$} & \multirow{2}{*}{$\begin{array}{l}\text { Start/Stop } \\
\text { nucleotides }\end{array}$} & \multicolumn{4}{|l|}{ Encoded Protein } \\
\hline & & id & Function & $\%$ of Identity ${ }^{a}$ & Comment \\
\hline BI322_RS06885 & $549463 / 550359$ & WP_024360046.1 & $\begin{array}{l}\text { UTP-glucose-1-phosphate } \\
\text { uridylyltransferase (GalF) }\end{array}$ & 99 & \\
\hline B1322_RS06890 & $550820 / 551449$ & WP_082236967.1 & $\begin{array}{l}\text { acid phosphatase (phosphatidic } \\
\text { acid phosphatase) }\end{array}$ & 98 & \\
\hline Bl322_RS06895 & $552089 / 552316$ & WP_082236968.1 & hypothetical protein & 0 & \\
\hline BI322_RS06900 & $552447 / 553886$ & WP_082236969.1 & $\begin{array}{l}\text { capsule assembly Wzi family } \\
\text { protein (Wzi) }\end{array}$ & 99 & \\
\hline BI322_RS06905 & $553960 / 555096$ & WP_082236970.1 & $\begin{array}{l}\text { polysaccharide export } \\
\text { protein (Wza) }\end{array}$ & 94 & $\begin{array}{l}\text { Wza is required for the translocation } \\
\text { of capsular polysaccharide through } \\
\text { the outer membrane. }\end{array}$ \\
\hline BI322_RS06910 & $555098 / 555538$ & WP_082236971.1 & $\begin{array}{l}\text { protein tyrosine phosphatase } \\
\text { (Wzb) }\end{array}$ & 88 & $\begin{array}{l}\text { Wzb shows phosphatase activity } \\
\text { towards the autophosphorylated } \\
\text { Wzc protein, which induces colanic } \\
\text { acid biosynthesis; catalyzes the } \\
\text { phosphorylation of UDP-glucose } \\
\text { dehydrogenase, an enzyme } \\
\text { involved in colanic acid biosynthesis. }\end{array}$ \\
\hline BI322_RS06915 & $555549 / 557714$ & WP_082236972.1 & tyrosine-protein kinase (Wzc) & 78 & $\begin{array}{l}\text { Wzc catalyzes the autophosphorylation } \\
\text { on tyrosine residues which } \\
\text { downregulates the biosynthesis } \\
\text { of colonic acid (an extracellular } \\
\text { polysaccharide). }\end{array}$ \\
\hline Bl322_RS06920 & $557836 / 559263$ & WP_082236973.1 & $\begin{array}{l}\text { undecaprenyl-phosphate } \\
\text { galactose phosphotransferase } \\
\text { (WbaP) }\end{array}$ & 0 & \\
\hline B1322_RS06925 & $559308 / 560219$ & WP_082236974.1 & rhamnosyltransferase & 0 & \\
\hline Bl322_RS06930 & $560570 / 561598$ & WP_082236975.1 & hypothetical protein & 31 & \\
\hline B1322_RS06935 & $561614 / 562714$ & WP_082236976.1 & EpsG family protein & 36 & $\begin{array}{l}\text { This family of proteins are related } \\
\text { to the EpsG protein from } \\
\text { Bacillus subtilis. These proteins } \\
\text { are likely glycosyl transferases } \\
\text { belonging to the membrane } \\
\text { protein GT-C clan. }\end{array}$ \\
\hline Bl322_RS06940 & $562727 / 563569$ & WP_082236977.1 & hypothetical protein & 44 & $\begin{array}{l}\text { Glycosyltransferase like family 2; } \\
\text { Members of this family of } \\
\text { prokaryotic proteins include } \\
\text { putative glucosyltransferase, } \\
\text { which are involved in bacterial } \\
\text { capsule biosynthesis. }\end{array}$ \\
\hline BI322_RS06945 & $563574 / 564449$ & WP_082236978.1 & hypothetical protein & 99 & $\begin{array}{l}\text { Glycosyltransferase, GT2 family, } \\
\text { putative dTDP-rhamnosyl } \\
\text { transferase. }\end{array}$ \\
\hline BI322_RS06950 & $564469 / 565359$ & WP_082236979.1 & hypothetical protein & 0 & $\begin{array}{l}\text { Glycosyltransferase like family 2; } \\
\text { Members of this family of } \\
\text { prokaryotic proteins include } \\
\text { putative glucosyltransferase, } \\
\text { which are involved in bacterial } \\
\text { capsule biosynthesis. }\end{array}$ \\
\hline B1322_RS06955 & $565408 / 566238$ & WP_082236980.1 & hypothetical protein & 36 & \\
\hline B1322_RS06960 & $566247 / 567692$ & WP_082236981.1 & $\begin{array}{l}\text { lipopolysaccharide } \\
\text { biosynthesis protein (Wzx) }\end{array}$ & 50 & $\begin{array}{l}\text { Membrane protein involved } \\
\text { in the export of O-antigen } \\
\text { and teichoic acid. }\end{array}$ \\
\hline B1322_RS06965 & $568041 / 569447$ & WP_082236982.1 & $\begin{array}{l}\text { NADP-dependent } \\
\text { phosphogluconate } \\
\text { dehydrogenase (Gnd) }\end{array}$ & 99 & $\begin{array}{l}\text { 6-phosphogluconate } \\
\text { dehydrogenase. }\end{array}$ \\
\hline
\end{tabular}


Table 2 The cps1 gene cluster of K. oxytoca DSM 29614 (Continued)

\begin{tabular}{|c|c|c|c|c|c|}
\hline \multirow{2}{*}{$\begin{array}{l}\text { Gene (Locus } \\
\text { tag) }\end{array}$} & \multirow{2}{*}{$\begin{array}{l}\text { Start/Stop } \\
\text { nucleotides }\end{array}$} & \multicolumn{4}{|l|}{ Encoded Protein } \\
\hline & & $\overline{i d}$ & Function & $\%$ of Identity ${ }^{a}$ & Comment \\
\hline BI322_RS06970 & $569654 / 570718$ & WP_082236983.1 & dTDP-glucose 4,6-dehydratase & 99 & \\
\hline Bl322_RS06975 & $570732 / 571601$ & WP_049099678.1 & $\begin{array}{l}\text { glucose-1-phosphate } \\
\text { thymidylyltransferase }\end{array}$ & 99 & \\
\hline BI322_RS06980 & $571633 / 572523$ & WP_082236984.1 & $\begin{array}{l}\text { dTDP-4-dehydrorhamnose } \\
\text { reductase }\end{array}$ & 99 & \\
\hline BI322_RS06985 & $572539 / 573093$ & WP_014230057.1 & $\begin{array}{l}\text { dTDP-4-dehydrorhamnose } \\
\text { 3,5-epimerase }\end{array}$ & 99 & \\
\hline BI322_RS06990 & $573267 / 574433$ & WP_082236985.1 & $\begin{array}{l}\text { UDP-glucose 6-dehydrogenase } \\
\text { (Ugd) }\end{array}$ & 99 & \\
\hline Bl322_RS06995 & $57599 / 576603$ & WP_082236986.1 & NAD-dependent epimerase & 99 & \\
\hline
\end{tabular}

a with the products of $K$. oxytoca strain homologues

and energy source under anaerobic conditions. This growth is characterized by the production of acetic acid - which is due to the involvement of CitEF, OadA, PFL, PTA and ACK during citrate anaerobic utilization [42] - and by the peculiar iron precipitation in the bacterial EPS - manly as nano-sized iron oxides and hydroxides [22] - with the concomitant massive reduction of $\mathrm{Fe}^{3+}$ to $\mathrm{Fe}^{2+}$. In general, ferric reducing bacteria, like the Gram-negative Shewanella and Geobacter spp., reduce $\mathrm{Fe}(\mathrm{III})$ to $\mathrm{Fe}(\mathrm{II})$ during the anaerobic respiration using $\mathrm{Fe}(\mathrm{III})$ as electron acceptor in a dissimilatory pathway [44-46]. As inferred from genome analysis, in the DSM 29614 strain, that does not possess genes orthologous to Shewanella and Geobacter genes involved dissimilatory pathways, cellular mechanisms controlling iron homeostasis may be taken into account for the massive reduction of $\mathrm{Fe}(\mathrm{III})$ to $\mathrm{Fe}(\mathrm{II})$, including the

Table 3 The cps2 gene cluster of K. oxytoca DSM 29614

\begin{tabular}{|c|c|c|c|c|c|}
\hline \multirow{2}{*}{$\begin{array}{l}\text { Gene (Locus } \\
\text { tag) }\end{array}$} & \multirow{2}{*}{$\begin{array}{l}\text { Start/Stop } \\
\text { nucleotides }\end{array}$} & \multicolumn{4}{|l|}{ Protein } \\
\hline & & $\mathrm{id}$ & Function & $\%$ of Identity ${ }^{a}$ & Comment \\
\hline BI322_RS19465 & $3164958 / 3166361$ & WP_004133794.1 & $\begin{array}{l}\text { undecaprenyl-phosphate } \\
\text { glucose phosphotransferase } \\
\text { (WcaJ) }\end{array}$ & 100 & \\
\hline BI322_RS19470 & $3166351 / 3167637$ & WP_004133795.1 & $\begin{array}{l}\text { capsular biosynthesis } \\
\text { protein (CpsB) }\end{array}$ & 100 & \\
\hline BI322_RS19475 & $3167634 / 3168188$ & WP_024359125.1 & $\begin{array}{l}\text { capsular biosynthesis } \\
\text { protein (CpsC) }\end{array}$ & 100 & $\begin{array}{l}\text { Periplasmic protein involved } \\
\text { in polysaccharide export. }\end{array}$ \\
\hline BI322_RS19480 & $3168190 / 3170277$ & WP_004133800.1 & $\begin{array}{l}\text { capsular polysaccharide } \\
\text { biosynthesis protein }\end{array}$ & 100 & \\
\hline BI322_RS19485 & $3170283 / 3171500$ & WP_004133805.1 & $\begin{array}{l}\text { capsular polysaccharide } \\
\text { biosynthesis protein }\end{array}$ & 99 & \\
\hline BI322_RS19490 & $3171491 / 3172873$ & WP_004133807.1 & hypothetical protein & 100 & \\
\hline BI322_RS19495 & $3172866 / 3173891$ & WP_004133808.1 & $\begin{array}{l}\text { family } 2 \text { glycosyl } \\
\text { transferase }\end{array}$ & 100 & \\
\hline BI322_RS19500 & $3173872 / 3175086$ & WP_024359127.1 & $\begin{array}{l}\text { glycosyltransferase } \\
\text { family } 1 \text { protein }\end{array}$ & 99 & \\
\hline BI322_RS19505 & $3175083 / 3176198$ & WP_004133810.1 & $\begin{array}{l}\text { glycosyltransferase } \\
\text { family } 1 \text { protein }\end{array}$ & 100 & \\
\hline BI322_RS19510 & $3176195 / 3176605$ & WP_004133811.1 & hypothetical protein & 100 & \\
\hline BI322_RS19515 & $3176608 / 3178026$ & WP_082237571.1 & $\begin{array}{l}\text { DUF4832 domain- } \\
\text { containing protein }\end{array}$ & 100 & \\
\hline BI322_RS19520 & $3178029 / 3178535$ & WP_004133814.1 & $\begin{array}{l}\text { colanic acid biosynthesis } \\
\text { acetyltransferase (WcaB) }\end{array}$ & 100 & $\begin{array}{l}\text { Serine acetyltransferase involved } \\
\text { in the biosynthesis of colanic acid, } \\
\text { an exopolysaccharide expressed } \\
\text { in Enterobacteraceae species. }\end{array}$ \\
\hline
\end{tabular}




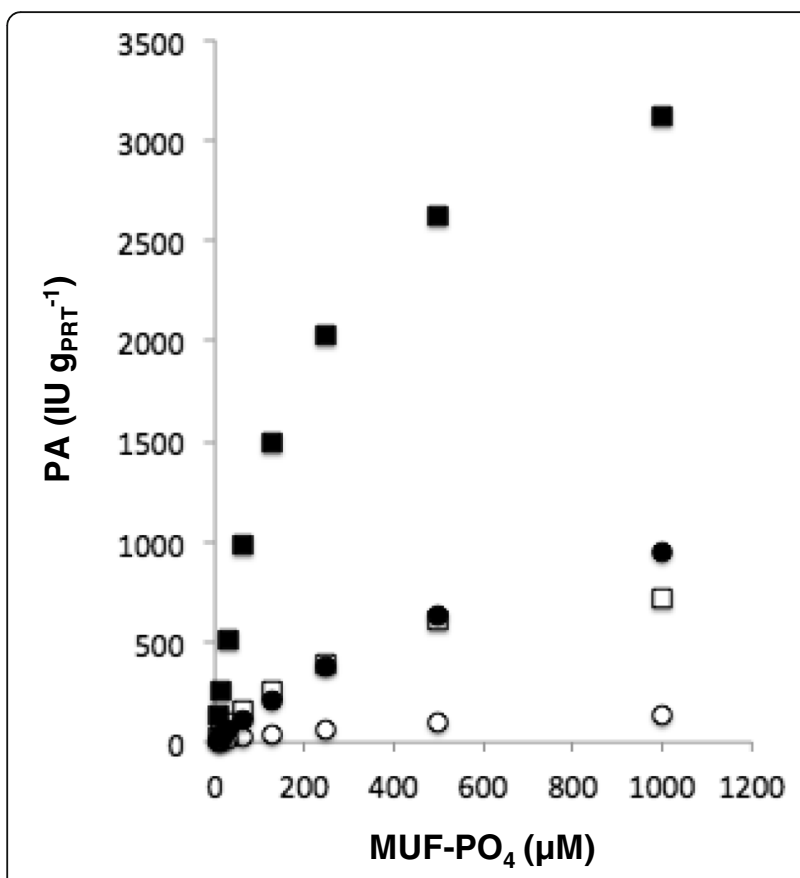

Fig. 7 Rate of phosphatase activity (PA), reported as IU per $\mathrm{g}$ of cell proteins, in whole cells of $K$. oxytoca DSM 29614 at different concentrations of the MUF- $\mathrm{PO}_{4}$ fluorescence substrate after: anaerobic (solid squares) and aerobic (empty squares) cultivation in $\mathrm{NaC}$ medium; anaerobic (solid circles) and aerobic (empty circles) cultivation in $\mathrm{FeC}$ medium

possible role of i) Flavin metal reductases, ii) specific efflux pumps and iii) siderophores. In addition, a direct contribution to $\mathrm{Fe}(\mathrm{II})$ production is to be ascribed to the peculiar EPS produced by DSM 29614 strain. In fact, more in general and in agreement with what described by Gupta et al. (2017) [54], the resistance of $K$. oxytoca DSM 29614 to different metals could be due to the synthesis of the EPS, which promotes metal cation entrapment and reduction with the production of metal NPs which finally resulted embedded into EPS matrix itself $[10,15-22$, 25].

One of the two cps clusters identified in K. oxytoca DSM 29614 genome, namely cps1, could be responsible for the biosynthesis of DSM 29614 EPS that was characterized by Leone et al. (2007) [11]. In fact, one of the most peculiar characteristics of this EPS is the

Table 4 Phosphatase activity with enzymatic kinetics parameters

\begin{tabular}{llllll}
\hline Growth medium & Condition & \multicolumn{2}{l}{$\mathrm{V}_{\max }\left(\mathrm{IU} \cdot \mathrm{gPRT}^{-1}\right)$} & \multicolumn{2}{l}{$\mathrm{K}_{\mathrm{m}}(\mu \mathrm{M})$} \\
\hline FeC & Aerobic & 0.19 & \pm 0.055 & 452 & \pm 30 \\
& Anaerobic & 0.73 & \pm 0.102 & 204 & \pm 87 \\
$\mathrm{NaC}$ & Aerobic & 0.83 & \pm 0.059 & 356 & \pm 75 \\
& Anaerobic & 4.02 & \pm 0.271 & 223 & \pm 15 \\
\hline
\end{tabular}

presence of the rare sugar rhamnose and cps1 contains genes encoding a rhamnosyltransferase (BI322_RS06925) and two proteins involved in rhamnose metabolism (BI322_RS06980 and BI322_RS06985). In addition, the presence of his genes associated with cps1 is noteworthy as well (Additional file 6: Table S4 and Additional file 5: Supporting Information), since histidine was observed as a major amino acid component of protein fraction associated with DSM 29614 strain EPS [14]. Histidine plays a role in metal homeostasis acting either as metal chelator free-amino acid and as metal-coordinating residues in proteins, like metal chaperones or histidine-rich proteins [55-59].

In addition, genes whose products are putatively involved in general and/or metal-specific resistance processes were detected in DSM 29614 genome. In particular, 149 genes were identified, globally accounting for specific resistance to 23 different kinds of metals. On the other hand, as an example of general metal-detoxifying strategies, Fe-SOD - contrasting the intracellular generation of superoxide - was so far shown accumulating in presence of Fe(III) during both anaerobic and aerobic growth (Gallo et al., 2012) [26] (Additional file 2: Table S2). Furthermore, phosphate salt precipitation as struvite [60] can play a role in general processes devoted to metal detoxification in $K$. oxytoca DSM 29614 as it can be inferred from TEM observations and from the oPA profile in $\mathrm{NaC}$ and FeC medium according to Yung et al. (2014) [61] and Montgomery et al. (1995) [62]. The struvite was obtained in K. oxytoca DSM 29614 cultivations only under aerobic conditions because of favourable $\mathrm{pH}$ conditions (around 8; Fig. 5a) [63]. Thus, $\mathrm{NH}^{+}$, $\mathrm{Mg}^{+}, \mathrm{PO}^{3-}$ and other cations, embedded in EPS, reach the critical supersaturation conditions typical of a nucleation site. Conversely, at $\mathrm{pH}<7$ struvite does not form, although high concentrations of $\mathrm{PO}^{3-}$ remains sequestered by EPS. Indeed, it has been demonstrated by EDS-SEM element-maps of Pd-Fe NPs that $\mathrm{Pd}$ was associated with $\mathrm{P}$ but not with $\mathrm{Fe}$ [20]. The finding that the addition of toxic heavy metals to $\mathrm{NaC}$ medium strongly stimulates oPA activity only in aerobiosis (Fig. 8b) suggest that heavy metal cations can be embedded into EPS which is massively produced in anaerobiosis while they can form metal ions-phosphate salts in aerobiosis. Thus, the different effect on oPA, observed comparing aerobic and anaerobic conditions upon heavy metal additions to cultivation medium, suggests an interplay between inorganic phosphate and EPS biosynthesis that may have consequences on metal resistance of $K$. oxytoca DSM 29614. In this context, it was previously observed in a phosphatase-overproducing Citrobacter sp. (NCIMB 

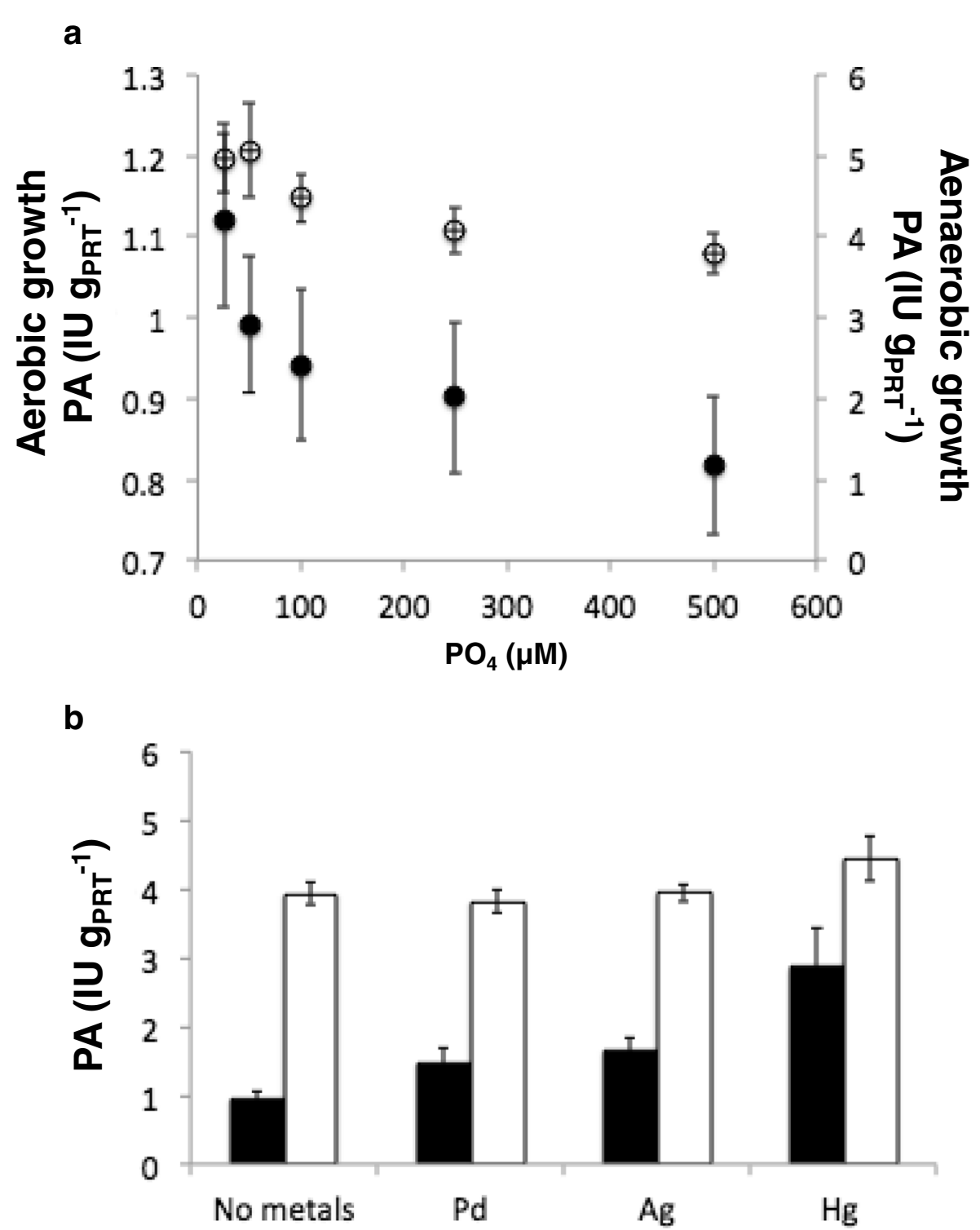

Fig. 8 a Inhibition of phosphatase activity (PA), reported as IU per $\mathrm{g}$ of cell proteins, by adding different amount of $\mathrm{PO}_{4}{ }^{-3}$ in $\mathrm{NaC}^{2}$ medium under aerobic (solid circles) and anaerobic (empty circles) condition. b Determination of PA in $\mathrm{NaC}$ medium with $\mathrm{Ag}^{+}, \mathrm{Hg}^{2+}$ and $\mathrm{Pd}^{2+}$ additions (50 mg. $\mathrm{I}^{-1}$ ) under aerobic (solid histograms) and anaerobic condition (empty histograms). Standard deviation values are reported as vertical bars

40259) grown in a bioreactor an interesting correlation between i) limitation of carbon, phosphorus or nitrogen, ii) the capability of liberating inorganic phosphate from an organic phosphate donor with the precipitation of metal cations as insoluble salt at the cell surface, and iii) biofilm formation [64]. In addition, a clear correlation between inorganic phosphate limitation and EPS production was observed in Mycobacteria [65].

\section{Conclusion}

The K. oxytoca DSM 29614 genome shows peculiar characteristics which confirm the view of an open pangenome for Klebsiella species which is in agreement with the wide distribution of member of Klebsiella genus. The K. oxytoca DSM 29614 unique capabilities of using Fe(III)-citrate as sole carbon and energy source in anaerobiosis and tolerating diverse metals coincides with the presence at the genomic level of specific genes that can support i) energy metabolism optimization, ii) cell protection by the biosynthesis of a peculiar exopolysaccharide armour entrapping metal ions and iii) general and metal-specific detoxifying activities by different proteins and metabolites. Therefore, K. oxytoca DSM 29614 strain can play a role in nano-biotechnological 
applications and in the study of bacterial adaptation to hazardous and metabolically demanding environments.

\section{Additional files}

Additional file 1: Table S1. List of genomes of $K$. oxytoca strains used for comparative genomics. (XLSX $10 \mathrm{~kb}$ )

Additional file 2: Table S2. List of differentially abundant proteins in DSM 29614 strain used for protein functional enrichment analysis. (XLSX 17 kb)

Additional file 3: Table S3. List of metal resistance genes identified in the DSM 29614 strain genome. (XLSX 48 kb)

Additional file 4: Figure S1. K. oxytoca DSM 29614 grown in $\mathrm{NaC}$ (left) and in FeC medium (right) after 7 day of incubation at $30^{\circ} \mathrm{C}$. Figure $\mathbf{S 2}$. $\mathrm{a}, \mathrm{b})$ Production of ortorhomboidal struvite in the presence of $\mathrm{Hg}^{2+}$ (a) and $\mathrm{Ag}^{+}(\mathrm{b})$; both crystals precipitated in aerobic cultures of $\mathrm{K}$. oxytoca DSM 29614. c,d) Micrographs of microcrystal of struvite by $K$. oxytoca DSM 29614 cells, grown in aerobic conditions in the presence of $\mathrm{Pd}^{2+}$ in transmission mode (c) and in fluorescence mode (d) with cells stained with DAPI. e) Micrographs of TEM of microcrystals of struvite coated by $\mathrm{Pd}^{2+}$. (PDF $527 \mathrm{~kb}$ )

Additional file 5: Supporting Information. (PDF $130 \mathrm{~kb}$ )

Additional file 6: Table S4. List of genes associate with cps 1 cluster in DSM 29614 strain. (XLSX 10 kb)

\section{Abbreviations}

Ag: Silver; As: Arsenic; Cd: Cadmium; cps: Capsule biosynthetic gene cluster; DAPI: 4',6-diamidino-2-phenylindole; EPS: Exopolysaccharide; Fe: Iron; FeC: Growth medium containing 50 mM Fe(III)-citrate; FEPCU: Fisher Exact Parent-Child Union; Hg: Mercury; MUF-PO : 4-methylumbelliferyl phosphate disodium salt; NaC: Growth medium containing 50 mM Na-citrate; NPs: Nanoparticles; PA: Phosphatase activity; Pb: Lead; Pd: Palladium; Rh: Rhodium; SOD: Superoxide dismutase; Zn: Zinc

\section{Acknowledgements}

Not applicable.

\section{Funding}

This work was supported by the Ministry of University and Scientific Research - MIUR (PRIN-2010AXENJ8 to FB; FFABR 2017 to GG), Cà Foscari University (ADiR to FB), University of Palermo (FFR 2012-2013 to AMP; FFR 2018 to GG). EP was founded by an "Assegno premiale" of the Department of Biology of the University of Florence. Funding bodies had not any role in the design of the study, in collection, analysis and interpretation of data, and in writing the manuscript.

\section{Availability of data and materials}

Genome sequence obtained in this study was deposited in the NCBI GenBank database with accession number MKCU00000000. Protein functional enrichment analyses are available in the BioCyc database as BioCyc Public Smart Tables (internet address https://biocyc.org/smarttables) with the titles "Enriched with FEPCU from anaerobic Vs aerobic growth on FeC up-regulated proteins" and "Enriched with FEPCU from FeC Vs NaC during anaerobic growth up-regulated proteins".

\section{Authors' contributions}

AMP, RF and FB conceived and designed the experiments. GG, LP, EP, MG and DM performed the experiments. All the authors contributed to write the manuscript and read and approved the final version.

\section{Ethics approval and consent to participate}

Not applicable

\section{Consent for publication}

Not applicable

\section{Competing interests}

The authors declare that they have no competing interests.

\section{Publisher's Note}

Springer Nature remains neutral with regard to jurisdictional claims in published maps and institutional affiliations.

\section{Author details}

${ }^{1}$ Laboratory of Molecular Microbiology and Biotechnology, Department of Biological, Chemical and Pharmaceutical Sciences and Technologies, Viale delle Scienze, ed. 16, 90128 Palermo, Italy. ${ }^{2}$ Laboratory of Microbial and Molecular Evolution, Department of Biology, University of Florence, Via Madonna del Piano 6, I-50019 Sesto F.no, Florence, Italy. ${ }^{3}$ Dipartimento di Scienze Molecolari e Nanosistemi, University Cà Foscari Venezia, Via Torino 155, 30172 Mestre, Venezia, Italy.

Received: 15 May 2018 Accepted: 29 October 2018

Published online: 27 November 2018

\section{References}

1. Martin RM, Bachman MA. Colonization, Infection, and the Accessory Genome of Klebsiella pneumoniae. Front Cell Infect Microbiol. 2018:8:4.

2. Yu Z, Li S, Li Y, Jiang Z, Zhou J, An Q. Complete genome sequence of N2fixing model strain Klebsiella sp. nov. M5al, which produces plant cell walldegrading enzymes and siderophores. Biotechnol reports. 2018;17:6-9.

3. Qamar N, Rehman Y, Hasnain S. Arsenic-resistant and plant growth-promoting Firmicutes and $y$-Proteobacteria species from industrially polluted irrigation water and corresponding cropland. J Appl Microbiol. 2017;123:748-58.

4. Sheik CS, Mitchell TW, Rizvi FZ, Rehman Y, Faisal M, Hasnain S, Mclnerney MJ, Krumholz LR. Exposure of soil microbial communities to chromium and arsenic alters their diversity and structure. PLoS One. 2012;7(6):e40059.

5. Hogenauer C, Langner C, Beubler E, Lippe IT, Schicho R, Gorkiewicz G, et al. Klebsiella oxytoca as a causative organism of antibiotic-associated hemorrhagic colitis. N Engl J Med. 2006;355:2418-26.

6. Pavlova AS, Leontieva MR, Smirnova TA, Kolomeitseva GL, Netrusov Al, Tsavkelova EA. Colonization strategy of the endophytic plant growthpromoting strains of Pseudomonas fluorescens and Klebsiella oxytoca on the seeds, seedlings and roots of the epiphytic orchid, Dendrobium nobile Lindl. J Appl Microbiol. 2017;123:217-32.

7. Cho S, Kim T, Woo HM, Kim Y, Lee J, Um Y. High production of 2,3butanediol from biodiesel-derived crude glycerol by metabolically engineered Klebsiella oxytoca M1. Biotechnol Biofuels. 2015;8:146.

8. Baldi F, Olson GJ. Effects of cinnabar on pyrite oxidation by Thiobacillus ferrooxidans and cinnabar mobilization by a mercury-resistant strain. Appl Environ Microbiol. 1987;53:772-6.

9. Baldi F, Bralia A, Riccobono F, Sabatini G. Bioleaching of cobalt and zinc from pyrite ore in relation to calcitic gangue content. World J Microbiol Biotechnol. 1991;7:298-308.

10. Baldi F, Marchetto D, Battistel D, Daniele S, Faleri C, De Castro C, et al. Ironbinding characterization and polysaccharide production by Klebsiella oxytoca strain isolated from mine acid drainage. J Appl Microbiol. 2009:107:1241-50.

11. Leone S, De Castro C, Parrilli M, Baldi F, Lanzetta R. Structure of the ironbinding exopolysaccharide produced anaerobically by the gram-negative bacterium Klebsiella oxytoca BAS-10. European J Org Chem. 2007;2007:5183-9.

12. Baldi F, Minacci A, Pepi M, Scozzafava A. Gel sequestration of heavy metals by Klebsiella oxytoca isolated from iron mat. FEMS Microbiol Ecol. 2001;36:169-74.

13. Casentini B, Rossetti S, Gallo M, Baldi F. Potentialities of biogenerated iron hydroxides nanoparticles in arsenic water treatment. Conference Proceedings $6^{\text {th }}$ European Bioremediation Conference, Chania, Crete, Greece. 2015.

14. Baldi F, Gallo M, Daniele S, Battistel D, Faleri C, Kodre A, et al. An extracellular polymeric substance quickly chelates mercury(II) with $\mathrm{N}$ heterocyclic groups. Chemosphere. 2017:176:296-304.

15. Baldi F, Marchetto D, Zanchettin D, Sartorato E, Paganelli S, Piccolo O. A biogenerated Fe(iii)-binding exopolysaccharide used as new catalyst for phenol hydroxylation. Green Chem. 2010;12:1405-9.

16. Arčon I, Piccolo O, Paganelli S, Baldi F. XAS analysis of a nanostructured iron polysaccharide produced anaerobically by a strain of Klebsiella oxytoca. Biometals. 2012;25:875-81.

17. Paganelli S, Piccolo O, Baldi F, Gallo M, Tassini R, Rancan M, et al. A new biogenerated Rh-based catalyst for aqueous biphasic hydroformylation. Catal Commun. 2015:71:32-6.

18. Paganelli S, Tassini R, La Sorella G, Piccolo O, Baldi F, Rathod VD. Aqueous biphasic treatment of some nitrocompounds with hydrogen in the presence of a biogenerated Pd-polysaccharide. New Biotechnol. 2015;32:313-7. 
19. Paganelli S, Piccolo O, Baldi F, Tassini R, Gallo M, La Sorella G. Aqueous biphasic hydrogenations catalyzed by new biogenerated Pd-polysaccharide species. Appl Catal A Gen. 2013;451:144-52.

20. Arčon I, Paganelli S, Piccolo O, Gallo M, Vogel-Mikuš K, Baldi F. XAS analysis of iron and palladium bonded to a polysaccharide produced anaerobically by a strain of Klebsiella oxytoca. J Synchrotron Radiat. 2015;22:1215-26.

21. Baldi F, Gallo M, Paganelli S, Tassini R, Sperni L, Piccolo O, et al. Hydrodechlorination of aroclor 1260 in aqueous two-phase mixture catalyzed by biogenerated bimetallic catalysts. Int Res J Pure Appl Chem. 2016;11:1.

22. Baldi F, Daniele S, Gallo M, Paganelli S, Battistel D, Piccolo O, et al. Polysaccharide-based silver nanoparticles synthesized by Klebsiella oxytoca DSM 29614 cause DNA fragmentation in E. coli cells. BioMetals. 2016;29:321-31.

23. Battistel D, Baldi F, Gallo M, Faleri C, Daniele S. Characterisation of biosynthesised silver nanoparticles by scanning electrochemical microscopy (SECM) and voltammetry. Talanta. 2015:132:294-300.

24. Buttacavoli M, Albanese NN, Di Cara G, Alduina R, Faleri C, Gallo M, et al. Anticancer activity of biogenerated silver nanoparticles: an integrated proteomic investigation. Oncotarget. 2018;9.

25. Picceri GG, Leonardi P, lotti M, Gallo M, Baldi F, Zambonelli A, et al. Bacteriaproduced ferric exopolysaccharide nanoparticles as iron delivery system for truffles (Tuber borchii). Appl Microbiol Biotechnol. 2018;102:1429-41.

26. Gallo G, Baldi F, Renzone G, Gallo M, Cordaro A, Scaloni A, et al. Adaptative biochemical pathways and regulatory networks in Klebsiella oxytoca BAS-10 producing a biotechnologically relevant exopolysaccharide during Fe(III)citrate fermentation. Microb Cell Factories. 2012;11:152.

27. Baldi F, Marchetto D, Paganelli S, Piccolo O. Bio-generated metal binding polysaccharides as catalysts for synthetic applications and organic pollutant transformations. New Biotechnol. 2011:29:74-8.

28. Bradford MM. A rapid and sensitive method for the quantitation of microgram quantities of protein utilizing the principle of protein-dye binding. Anal Biochem. 1976;72:248-54

29. Perrin E, Fondi M, Maida I, Mengoni A, Chiellini C, Mocali S, et al. Genomes analysis and bacteria identification: the use of overlapping genes as molecular markers. J Microbiol Methods. 2015;117:108-12.

30. Presta L, Bosi E, Fondi M, Maida I, Perrin E, Miceli E, et al. Phenotypic and genomic characterization of the antimicrobial producer Rheinheimera sp. EpRS3 isolated from the medicinal plant Echinacea purpurea: insights into its biotechnological relevance. Res Microbiol. 2017;168:293-305.

31. Cox MP, Peterson DA, Biggs PJ. SolexaQA: At-a-glance quality assessment of Illumina second-generation sequencing data. BMC Bioinformatics. 2010;11:485.

32. Simpson JT, Wong K, Jackman SD, Schein JE, Jones SJM, Birol I. ABySS: a parallel assembler for short read sequence data. Genome Res. 2009;19:1117-23.

33. Bosi E, Donati B, Galardini M, Brunetti S, Sagot M-F, Lio P, et al. MeDuSa: a multi-draft based scaffolder. Bioinformatics. 2015;31:2443-51.

34. Page AJ, Cummins CA, Hunt M, Wong VK, Reuter S, Holden MTG, et al. Roary: rapid large-scale prokaryote pan genome analysis. Bioinformatics. 2015;31:3691-3.

35. Blin K, Medema MH, Kazempour D, Fischbach MA, Breitling R, Takano E, et al. antiSMASH 2.0-a versatile platform for genome mining of secondary metabolite producers. Nucleic Acids Res. 2013:41:W204-W212.

36. Pal C, Bengtsson-Palme J, Rensing C, Kristiansson E, Larsson DGJ. BacMet: antibacterial biocide and metal resistance genes database. Nucleic Acids Res. 2014;42:D737-43.

37. Travers M, Paley SM, Shrager J, Holland TA, Karp PD. Groups: knowledge spreadsheets for symbolic biocomputing. Database. 2013;2013:bat061.

38. DuBois M, Gilles KA, Hamilton JK, Rebers PA, Smith F. Colorimetric method for determination of sugars and related substances. Anal Chem. 1956;28:350-6.

39. Battistel D, Baldi F, Marchetto D, Gallo M, Daniele S. A rapid electrochemical procedure for the detection of hg(0) produced by mercuric-reductase: application for monitoring hg-resistant bacteria activity. Environ Sci Technol. 2012:46:10675-81

40. Hoppe HG. Significance of exoenzymatic activities in the ecology of brackish water: measurements by means of methylumbelliferyl-substrates. Mar Ecol Prog Ser. 1983;11:299-308

41. Tatusov RL, Galperin MY, Natale DA, Koonin EV. The COG database: a tool for genome-scale analysis of protein functions and evolution. Nucleic Acids Res. 2000;28:33-6.

42. Dimroth $P$, Jockel $P$, Schmid M. Coupling mechanism of the oxaloacetate decarboxylase $\mathrm{Na}(+)$ pump. Biochim Biophys Acta. 2001;1505:1-14.

43. Shi L, Squier TC, Zachara JM, Fredrickson JK. Respiration of metal (hydr)oxides by Shewanella and Geobacter: a key role for multihaem c-type cytochromes. Mol Microbiol. 2007;65:12-20.
44. Lovley DR, Holmes D, Nevin KP. Dissimilatory Fe(III) and Mn(IV) reduction. Adv Microb Physiol. 2004:49:219-86.

45. Schroder I, Johnson E, de Vries S. Microbial ferric iron reductases. FEMS Microbiol Rev. 2003:27:427-47.

46. Reyes-Ramirez F, Dobbin P, Sawers G, Richardson DJ. Characterization of transcriptional regulation of Shewanella frigidimarina Fe(III)-induced flavocytochrome $\mathrm{c}$ reveals a novel iron-responsive gene regulation system. J Bacteriol. 2003;185:4564-71.

47. Braun V. Iron uptake by Escherichia coli. Front Biosci. 2003;8:s1409-21.

48. Fontecave M, Covès J, Pierre J-L. Ferric reductases or flavin reductases? Biometals. 1994;7:3-8.

49. Han AW, Sandy M, Fishman B, Trindade-Silva AE, Soares CAG, Distel DL, et al. Turnerbactin, a novel triscatecholate siderophore from the shipworm endosymbiont Teredinibacter turnerae T7901. PLoS One. 2013;8:e76151.

50. Santos-Beneit $F$. The pho regulon: a huge regulatory network in bacteria. Front Microbiol. 2015;6:402

51. Holt KE, Wertheim H, Zadoks RN, Baker S, Whitehouse CA, Dance D, et al. Genomic analysis of diversity, population structure, virulence, and antimicrobia resistance in Klebsiella pneumoniae, an urgent threat to public health. Proc Natl Acad Sci U S A. 2015:112:E3574-81.

52. Podschun $\mathrm{R}$, Ullmann U. Klebsiella spp. as nosocomial pathogens: epidemiology, taxonomy, typing methods, and pathogenicity factors. Clin Microbiol Rev. 1998;11:589-603.

53. Bagley ST. Habitat association of Klebsiella species. Infect Control. 1985;6:52-8.

54. Gupta P, Diwan B. Bacterial exopolysaccharide mediated heavy metal removal: a review on biosynthesis, mechanism and remediation strategies. Biotechnol Rep. 2017;13:58-71.

55. Dietl A-M, Amich J, Leal S, Beckmann N, Binder U, Beilhack A, et al. Histidine biosynthesis plays a crucial role in metal homeostasis and virulence of Aspergillus fumigatus. Virulence. 2016;7:465-76.

56. Cheng T, Xia W, Wang P, Huang F, Wang J, Sun H. Histidine-rich proteins in prokaryotes: metal homeostasis and environmental habitat-related occurrence. Metallomics. 2013:5:1423-9.

57. Haydon MJ, Cobbett CS. Transporters of ligands for essential metal ions in plants. New Phytol. 2007:174:499-506.

58. Coombs JM, Barkay T. New findings on evolution of metal homeostasis genes: evidence from comparative genome analysis of bacteria and archaea. Appl Environ Microbiol. 2005;71:7083-91.

59. Krämer U, Cotter-Howells JD, Charnock JM, Baker AJM, Smith JAC. Free histidine as a metal chelator in plants that accumulate nickel. Nature. 1996; 379:635.

60. Schütze E, Weist A, Klose M, Wach T, Schumann M, Nietzsche S, et al. Taking nature into lab: biomineralization by heavy metal-resistant streptomycetes in soil. Biogeosciences. 2013;10:3605-14.

61. Yung MC, Jiao Y. Biomineralization of uranium by PhoY phosphatase activity aids cell survival in Caulobacter crescentus. Appl Environ Microbiol. 2014;80: 4795-804.

62. Montgomery DM, Dean AC, Wiffen P, Macaskie LE. Phosphatase production and activity in Citrobacter freundii and a naturally occurring, heavy-metalaccumulating Citrobacter sp. Microbiology. 1995;141(Pt 1):2433-41.

63. Doyle JD, Parsons SA. Struvite formation, control and recovery. Water Res. 2002;36:3925-40.

64. Allan VJM, Callow ME, Macaskie LE, Paterson-Beedle M. Effect of nutrient limitation on biofilm formation and phosphatase activity of a Citrobacter sp. Microbiology. 2002;148:277-88.

65. van de Weerd R, Boot M, Maaskant J, Sparrius M, Verboom T, van Leeuwen LM, et al. Inorganic phosphate limitation modulates capsular polysaccharide composition in Mycobacteria. J Biol Chem. 2016;291:11787-99. 